\title{
New Guidelines for SoTL in History: A Discipline Considers the SoTL Turn?
}

Richard Hughes

Illinois State University

The last decade has included significant milestones in terms of the relationship between the discipline of history and the Scholarship of Teaching and Learning (SoTL). Such developments offer an instructive opportunity to reflect on the state of the field within history and suggest that SoTL, while currently holding a limited and inconsistent position in terms of practice among historians, provides a promising opportunity for growth as history educators increasingly reframe the teaching and learning of the discipline around the skills of historians. While historians have discussed the teaching of history since the founders of the American Historical Association (AHA) claimed at its first meeting in 1884 that "few of the American universities give as yet any adequate historical instruction," the AHA's Tuning Project reflects new, concerted efforts to define the discipline in terms of "the distinctive skills, methods, and substantive range of [the] field." "The Tuning Project's establishment of "Core Competencies and Learning Outcomes" in 2013 and its revision of the document in 2016 reflected the challenges of establishing a clear consensus regarding what students should know and understand after completing a history major. The Tuning Project's focus on core competencies in history did not include any overt references to SoTL research. However, the efforts of the AHA, as the oldest and most prominent professional organization of historians in the

\footnotetext{
1 "First Meeting of the American Historical Association (1884)," https:// www.historians.org/about-aha-and-membership/aha-history-and-archives/ historical-archives/first-meeting-of-the-american-historical-association; "Tuning the History Discipline in the United States," https://www.historians.org/ teaching-and-learning/tuning-the-history-discipline.
}

(c) 2019 Hughes. Free to copy and share for education and scholarship under a Creative Commons Attribution NonCommercial-NoDerivatives 4.0 License. 
United States, to articulate the essential nature of the discipline and discreet learning outcomes for students of history was important for SoTL researchers. In addition to emphasizing inquiry skills rather than knowledge for five of the six learning outcomes, the Tuning Project articulated the specific ingredients of the history classroom that inform the questions, methods, and evidence of SoTL research in history. ${ }^{2}$

At the same time, historians acknowledged the challenge of assessing such learning goals, and in 2016, a special section of The Journal of American History focused on the current state of assessment in the field. Anne Hyde, who chaired the Tuning Project Leadership Core as then-chair of the AHA's Teaching Division, penned "Five Reasons Why Historians Suck at Assessment." This essay identified the substantial obstacles toward getting historians to embrace assessment as a key ingredient in teaching and learning. Hyde noted that historians frequently perceive assessment as not part of their responsibilities as teachers, disagree on learning goals in the classroom, and, in part due to a lack of expertise in educational assessment, struggle to assess the sort of learning often valued in history courses. Finally, Hyde explained how historians often associate assessment with the larger context of unpleasant and seemingly irrelevant academic and cultural politics. While a number of the essays in the section reflected the perspective that, at best, the efforts of historians to develop valuable approaches to assessment were a necessary hazard if only to keep others from imposing their assessments on historians, Hyde and others acknowledged the potential of rigorous assessment as a "shared set of tools" to improve curriculum and instruction. ${ }^{3}$ Rather than what two of the authors lamented as "reflexive hostility to assessment," such exploratory efforts to better measure student

\footnotetext{
2 "AHA History Tuning Project: 2016 History Discipline Core," https://www. historians.org/teaching-and-learning/tuning-the-history-discipline/2016-historydiscipline-core.

3 Anne Hyde, "Five Reasons History Professors Suck at Assessment," The Journal of American History 102 no. 4 (2016): 1104-1107.
} 
learning in history classrooms are increasingly perceived as, according to Scott E. Casper and Laura M. Westhoff, "surprising opportunities" and "forces for positive change." As an endeavor focused on identifying problems, collecting evidence, and sharing conclusions related to pedagogy, SoTL research is especially well-suited for assisting individual instructors and departments of history in the creation, implementation, evaluation, and dissemination of meaningful assessments in the discipline.

Most recently, the AHA appears to have endorsed this argument. In January 2019, the AHA Council approved and publicized "Guidelines for the Incorporation of the Scholarship of Teaching and Learning in the Work of the History Profession." Authored by Natalie Mendoza, David Pace, and Laura Westhoff, the ambitious statement explained how "historians contribute to SoTL in five significant ways" and that, in addition to "its own value as an independent area of inquiry," SoTL research in history can provide "major contributions to our profession at all levels from K-12 through graduate programs." First, historians engaged in SoTL research forge a research agenda through which they "define intellectual problems in the field, systematically collect evidence, come to reasonable conclusions, and place their work in the context of a larger body of literature." Second, historians enrich their own work in the classroom as "scholarly teachers" through an understanding of "an evidence-based body of literature." Third, historians, informed by SoTL research, contribute to the development of "classroom practice, curriculum development, and faculty rewards and recognition." Fourth, SoTL research has great potential to play a key role in the "training of the next generation of historians" who will spend much of their careers in the classroom. Finally, the statement argued that the "AHA has the responsibility to promote this work, uphold standards for its

4 Scott E. Casper and Laura M. Westhoff, "Surprising Opportunities for Historians: Taking Control of the Assessment Process," The Journal of American History 102, no. 4 (2016): 1102-1103. 
practice, and recognize its study as a scholarly endeavor and a means of improving the quality of teaching and learning in the discipline." ${ }^{5}$

However, the 2019 program from the AHA's annual conference in Chicago, where the organization approved the SoTL guidelines, provides a revealing measure of the current and limited status of SoTL within the discipline. On the positive side, HistorySoTL: The International Society for the Scholarship of Teaching and Learning in History, an affiliated organization of the AHA, hosted a workshop on "Enduring Problems for History Teachers (and How to Manage Them)" which addressed such issues as historical literacy, curriculum and coverage, and assessment. ${ }^{6}$ HistorySoTL has hosted successful workshops at AHA national conferences since 2016. Although there are many reasons for optimism, the AHA conference, the preeminent gathering of professional historians in the country, also demonstrated the precarious position of SoTL within the discipline. The 2019 conference program included at least twenty-six sessions dedicated to teaching, second only to the general topic of "profession" (which often also included discussions of teaching) and far more than such traditional historical topics as war, gender, religion, immigration, race, and politics. ${ }^{7}$ However, while the exact nature of each presentation is difficult to discern from the program, it seems clear that, with a few notable exceptions such as Lendol Calder's research on assessing the historical thinking of undergraduates, the sessions largely reflected what the SoTL guidelines identified

\footnotetext{
5 "Guidelines for the Incorporation of the Scholarship of Teaching and Learning in the Work of the History Profession (2019)," https://www.historians.org/jobsand-professional-development/statements-standards-and-guidelines-of-thediscipline/guidelines-for-the-incorporation-of-the-scholarship-of-teaching-andlearning-in-the-work-of-the-history-profession.

6 "HistorySoTL: The International Society for the Scholarship of Teaching and Learning in History," http://www.indiana.edu/ histsotl/blog/.

7 American Historical Association Annual Conference Program 2019, https:// www.historians.org/annual-meeting/past-meetings/2019-annual-meeting/2019program.
} 
as "wisdom of practice" presentations that describe the thoughtful work of accomplished teachers but are, as the new guidelines emphasize, "distinct from the theoretical and evidence-based exploration of pedagogical issues in the scholarship of teaching and learning." 8 Program abstracts mentioned such valuable topics as reflective practice, student engagement, and instructional strategies associated with important historical topics. However, such abstracts provided no hint that the teaching presentations centered on research problems, the analysis of evidence, or the burgeoning SoTL literature in history or related disciplines. In other words, the same conference that included the official adoption of SoTL guidelines for historians included little evidence that many scholars have embraced the sort of projects outlined in the guidelines.

Yet, two academic journals, The History Teacher, established in 1967, and Teaching History: A Journal of Methods, established in 1976, have taken deliberate steps to solicit and publish more articles related to SoTL research as further evidence of a discipline increasingly oriented toward SoTL. ${ }^{9}$ This change reflects, in part, the impact of seminal scholarship most often associated with secondary history education. Works such as Sam Wineburg's Historical Thinking and Other Unnatural Acts (2001), Bruce VanSledright's The Challenge of Rethinking History Education (2011), and Peter Seixas and Tom Morton's The Big Six: Historical Thinking Concepts (2012), to name just three books, signified a revolution in history education that increasingly reframed the teaching and learning of history around the cognitive skills of

\footnotetext{
8 "Guidelines for the Incorporation of the Scholarship of Teaching and Learning in the Work of the History Profession (2019)" https://www.historians.org/jobsand-professional-development/statements-standards-and-guidelines-of-thediscipline/guidelines-for-the-incorporation-of-the-scholarship-of-teaching-andlearning-in-the-work-of-the-history-profession. 9 The History Teacher, https://www.thehistoryteacher.org/; Teaching History: A Journal of Methods, https://openjournals.bsu.edu/teachinghistory.
} 
historians. ${ }^{10}$ Joel M. Sipress and David J. Voelker have noted that historians increasingly explored ways to address the "dichotomy between history as a 'way of knowing' and history as a subject to be learned." ${ }^{11}$ And, importantly, Peter Felton, a historian from Elon University, served as President of the International Society for the Scholarship of Teaching and Learning (ISSOTL) from 2016-2017, while the current president of the prominent organization is Mills Kelly, a historian from George Mason University. Conference programs from ISSOTL meetings indicate that historians have a presence in this larger body of research. ${ }^{12}$

Recent years have also included prominent publications on SoTL from historians, such as David Pace's Decoding the Disciplines Paradigm (2017) and Joan Middendorf and Leah Shopkow's Overcoming Student Learning Bottlenecks (2018), as well as a growing number of journal articles and book chapters such as Lendol Calder and Tracy Steffes' chapter in Improving Quality in American Education (2016) entitled, "Measuring

10 Sam Wineburg, Historical Thinking and Other Unnatural Acts: Charting the Future of Teaching the Past (Philadelphia, PA: Temple University Press: 2001); Bruce VanSledright, The Challenge of Rethinking History Education: On Practices, Theory, and Policy (New York: Routledge, 2011); Peter Seixas and Tom Morton, The Big Six: Historical Thinking Concepts (Toronto: Nelson Publishing, 2012). 11 Joel M. Sipress and David J. Voelker, "From Learning History to Doing History," in Exploring Signature Pedagogies: Approaches to Teaching Disciplinary Habits of Mind, eds. Regan A. R. Gurung, Nancy L. Chick, and Aeron Haynie (Sterling, VA: Stylus, 2009), 19-35.

12 Recent examples of work by historians at ISSOTL meetings include Sara Sundberg's session entitled, "Reacting to the Past: Qualitative Assessment of History Learning in the Undergraduate Classroom" and a session on a graduate history course led by Kelly Schrum and Amy Swan entitled, "Finding the 'Ah-ha' Moment: Using Digital Spaces to Scaffold Inquiry-Based Learning." The 2018 ISSOTL conference, held in Bergan Norway, included a panel entitled, "Resourcing the History Discipline: Learning Cultures in Australian and British Universities" by historians Adele Nye, Peter D'Sena, and Jennifer Clark. It underscored the increasingly global nature of SoTL work in history and the potential for international and comparative research projects. See ISSOTL Annual Conference Programs at https://www.issotl.com/2018. 
College Learning in History." ${ }^{13}$ In the research sponsored by the Social Science Research Council and informed by Measuring College Learning Panels, Calder and Steffes surveyed "the History of History Learning Outcomes." They identified the increasing commitment of historians to teaching historical thinking rather than courses limited to "cultural literacy, historical knowledge, or specific content." They also outlined the "Essential Concepts" and "Essential Competencies" that historians can use to drive assessment and SoTL research in history and to make meaningful decisions about curriculum and classroom instruction. ${ }^{14}$

The project described five core concepts for students in history:

1. History: History is an interpretive account of the past supported by evidence that survives.

2. The Past: Recognizing the "pastness of the past" directs historians to understand people of the past by contextualizing their actions.

3. Historical Evidence: Historians use primary and secondary sources to make sense of the past.

4. Complex Causality: Historical accounts are multiple and layered, avoiding monocausal explanations and reductionist thinking.

5. Significance: The indefinite standard by which historians determine what questions are worth asking; what parts of the past are worth teaching, learning, and remembering.

Similarly, students in history should be able to demonstrate

\footnotetext{
13 Lendol Calder and Tracy Steffes, "Measuring College Learning in History," in Improving Quality in American Higher Education: Learning Outcomes and Assessments for the $21^{\text {st }}$ Century, eds. Richard Arum, Josipa Roksa, and Amanda Cook (San Francisco, CA: Jossey-Bass, 2016), 37-86.

14 Social Science Research Council, "Measuring College Learning Project + Resource Center," http://highered.ssrc.org/projects/measuring-college-learningproject/history/.
} 
four fundamental skills:

1. Evaluate Historical Accounts: Identify an author's interpretation and critically scrutinize the evidence and analysis used to support it.

2. Interpret Primary Sources: Assess the credibility of sources and make judgements about their usefulness and limitations as evidence about the past.

3. Apply Chronological Reasoning: Take account of the role of time, sequencing, and periodization in historical narratives.

4. Construct a historical argument using primary sources... that demonstrate understanding of historical concepts, especially the nature of historical evidence, interpretation, and perspective. $^{15}$

These important concepts and skills are, according to the authors, crucial to communicating the "value of historical study" and establishing "its value with evidence."16 Not only has SoTL research in history informed the conclusions of the Measuring College Learning panels, SoTL projects in history offer an unparalleled way to systematically examine, measure, and publicize the effectiveness of pedagogy aimed at promoting such concepts and skills.

Advocating for the increased practice of SoTL to promote and assess the effective teaching of history may be even more important than simply improving classroom instruction. The AHA's muchdiscussed 2018 "History Majors Report" detailed the sharp decline in the number of history majors in American colleges in recent years. ${ }^{17}$.The report's author, Benjamin M. Schmidt, stressed the

\section{Ibid.}

16 Calder and Steffes, 37.

17 Benjamin M. Schmidt, "The History BA Since the Great Recession: The 2018 AHA Majors Report,” November 26, 2018, https://www.historians.org/ publications-and-directories/perspectives-on-history/december-2018/thehistory-ba-since-the-great-recession-the-2018-aha-majors-report. 
impact of the economic recession on shaping the perspectives of undergraduate students toward the history major and the liberal arts in general. Others have argued that the decreasing interest of history departments in political, military, and economic history since the ascendance of social history in the 1960s is to blame for the "slow-motion suicide" of the discipline. ${ }^{18}$ As the AHA released its report on the decline of majors, Jill Lepore, Harvard historian and frequent writer for The New Yorker, argued in an interview in The Chronicle of Higher Education that the demise of history stemmed from the unfortunate retreat of historians from the larger dialogue of public intellectuals. ${ }^{19}$ National publications such as The New Yorker and Time Magazine commented on the "The Decline of Historical Thinking" and the importance of studying the past at a time in which citizens need "historical knowledge and historical perspectives" to make sense of the world. ${ }^{20}$

While such reactions may include as much hyperbole as insight, growing concerns over the health of the discipline in secondary and higher education is ultimately the strongest argument for embracing SoTL research. For example, in contrast to older notions of history education that revolved around students mastering essential historical narratives, recent SoTL projects have emphasized "decoding the discipline" and the need to identify and address the key "threshold concepts" and "bottlenecks" within the discipline that shape the progress of history students within our classes and across the curriculum. ${ }^{21}$ The Scholarship of Teaching

18 Hal Brands and Francis J. Gavin, "The Historical Profession is Committing Slow-Motion Suicide," War on the Rocks, December 10, 2018.

19 Evan Goldstein, "The Academy is Largely Itself Responsible for Its Own Peril,"

The Chronicle of Higher Education, November 13, 2018, https://www.chronicle. com/article/The-Academy-Is-Largely/245080.

20 Eric Alterman, "The Decline of Historical Thinking, "The New Yorker, February 4, 2019, https://www.newyorker.com/news/news-desk/the-declineof-historical-thinking; Jason Steinhauer, "Fewer Students are Majoring in History, But We're Asking the Wrong Questions about Why," Time Magazine, December 6, 2018, https://time.com/5472828/history-majors/.

21 David Pace, Decoding the Disciplines Paradigm (Bloomington, IN: Indiana 
and Learning offers the best opportunity for a clear, rigorous, and public alternative to discussions of history education far too often characterized by anecdotal evidence, tradition, and cultural debates. In addition to the intellectual engagement of exploring "scholarly arguments about pedagogy," SoTL provides instructors with the sort of rich evidence of teaching and learning needed to create what Sipress and Voelker described as a "signature pedagogy" that will enable historians to better articulate the nature and value of history education in the twenty-first century.22

University Press, 2018); http://decodingthedisciplines.org/; Leah Shopkow, Arlene Diaz, Joan Middendorf, and David Pace, "The History Learning Project 'Decodes' a Disicpline," in Ebbs, Flows, and Rips: The Scholarship of Teaching and Learning In and Across Disciplines, ed. Kathleen McKinney (Bloomington, IN: Indiana University Press, 2012); Leah Shopkow, "From Bottlenecks to Epistemology in History: Changing the Conversation about the Teaching of History in Colleges and Universities," in Changing the Conversation About Higher Education, ed. Robert Thompson (Lanham, MD: Rowman \& Littlefield Education, 2013).

22 Sipress and Voelker, 32. 